\title{
A kriptovaluták és az e-bizalom kapcsolata $^{1}$
}

\section{DORNFELD László ${ }^{2}$}

\begin{abstract}
A kriptovaluták kapcsán élénk diskurzus folyik mind a közbeszédben, mind a tudományos életben. Egyesek a jövő úttörő technológiájának tartják, mások jóval szkeptikusabbak alkalmazásának lehetőségeit illetően. A kriptovalutákkal kapcsolatos vizsgálódásban nemcsak az anonimitás és a harmadik fél kizárásának igénye emelendő ki, de a bizalom szerepe is, hiszen apropóját a társadalom bizalomvesztése adta, kitalálói pedig egy bizalmat nem igénylő rendszert kívántak megalkotni.

Az egyéves kutatás eredményeit összegzö, többrészesre tervezett tanulmánysorozat első írása bemutatja a kriptovalutákkal kapcsolatos fogalmi kérdéseket és vitákat, a kriptovaluták elméleti alapjait és müködését, valamint a kriptopiacokat és azok fö szereplőit. Ennek az elméleti alapozó írásnak a legföbb célja, hogy képet nyújtson a téma alapjairól, amely jobban érthetővé teszi majd a kriptovaluták és a bünözés kapcsolatának vizsgálatát a későbbi tanulmányokban. Ez egyúttal komplex megközelítését is lehetővé teszi, hiszen az e-bizalommal kapcsolatos és a kriminológiai szempontok összefüggéseire világhíthat rá.
\end{abstract}

Kulcsszavak: kriptovaluta, blokklánc, bitcoin, e-bizalom

\section{Bevezetés}

A kriptovaluták létrejötte szorosan kapcsolódik a bizalom kérdéséhez. Az alapjául szolgáló blokklánc- (blockchain-) technológia 2008 novemberében kapott nagyobb figyelmet, amikor valaki(k) Satoshi Nakamoto álnév alatt javaslattervet tett(ek) közzé a Cryptography levelezőlistán, amely forradalmian új megoldást mutatott be a központi elszámoló felek által müködtetett fizetési rendszerekhez képest. Korábban a digitális tranzakció csak úgy volt lehetséges, hogy arról duplikátum keletkezett, amelyet a felek egy mindkettejük által megbízhatónak tartott harmadik félre (a pénzintézet) bíztak. Azonban a 2008-as nagy pénzügyi válság, a bankokba és pénzügyi közvetítőkbe vetett bizalom hiánya elvezetett oda, hogy felmerüljön

\footnotetext{
A tanulmány a Nemzeti Közszolgálati Egyetem Eötvös József Kutatóközpont 2020. évi kutatói pályázatának támogatásával készült.

2 Dr. Dornfeld László, Nemzeti Közszolgálati Egyetem Eötvös József Kutatóközpont, Kiberbiztonsági Kutatóintézet, kutató.

László Dornfeld PhD candidate, University of Publice Service, Eötvös József Research Centre, Institute of Cyber Security, Researcher. E-mail: dr.laszlo.drornfeld@gmail.com
} 
az igény a közvetítő nélküli tranzakciókra. ${ }^{3}$ A cél egy olyan rendszer kialakítása volt, amely alapvetően bizalommentes, kizárólag a kapcsolódó matematikai számítások jelentik az alapját.

Satoshi Nakamoto már említett kilencoldalas javaslata a Bitcoin ${ }^{4}$ nevet kapta. Ez volt minden idők legelső kriptográfiai alapokon nyugvó, decentralizált és bizalommentes fizetési technológia koncepciója, amelynek legfőbb célja a valós idejü fizetések lebonyolítására való képesség mellett a központi harmadik féltől - aki nyomon követi, teljesíti, elszámolja a pénzforgalmat, valamint számlát vezet a szereplőknek - független, megosztott nyilvántartási könyv létrehozása volt. Ebben a fő problémát az a kihívás jelentette, hogy meg kellett találni a módot arra, hogy egy adott pénzegység csak egyszer legyen elkölthető, vagyis kizárható legyen a hamisítás lehetősége. Ezt Satoshi úgy kívánta áthidalni, hogy egyenlő felek közötti peerto-peer (azaz egymással közvetlenül kommunikáló számítógépek segítségével), mindenki számára nyitott és elérhető hálózaton zajlanak a tranzakciók és azok hitelesítése. A tranzakciót elindító a teljes közösség előtt bejelenti tranzakciós szándékát, illetve a lényeges információkat a tranzakcióval kapcsolatosan, és egy egyedi azonosítóval is ellátja azt. A hálózat többi résztvevője pedig hitelesíti ezt a bejelentett tranzakciót.

Az igazán forradalmi megoldás azonban az, hogy a tranzakciók hitelesítését szabadpiaci alapokra helyezve érdekeltté teszi benne a hálózaton lévőket, sőt versenyezteti is őket. Ennek módja az, hogy a hitelesítéshez használt véletlenszerúen generált hashkódok nagy erőforrás-igényes visszafejtésének elvégzése után az abban részt vevők jutalomban részesülnek. Ez a jutalom a bitcoin, míg a hitelesítésben részt vevők a történelmi aranyásók mintájára a bányászok. Maga a folyamat ma kriptovalutabányászatként lehet ismert sokak számára. Ezáltal nemcsak kizárható a központi fél az egész rendszerből, de a verseny biztosítja azt, hogy az így keletkezett rendszer működőképes és fenntartható legyen, valamint elejét vegye a visszaéléseknek. ${ }^{5}$

Kevés megosztóbb technológia létezik manapság, mint a kriptovaluták. Számos érvet sorakoztatnak fel pro és kontra annak támogatói, a „Bitcoin evangelisták” és ellenzői egyaránt. Ezeket mind lehetetlen lenne végigtekinteni, és nem is célja ennek a tanulmánynak. A vizsgálódás alapvetően a bűnügyi szempontból is releváns kérdésekre terjed ki. Elsősorban fontos érteni a technológia múködését, ennek jellemzőit és korlátait, valamint a fogalmi kérdések is fontosak lehetnek. Gondoljunk csak arra, hogy milyen jelentősége van a pénzmosás megállapításánál annak, hogy

\footnotetext{
Alapjogokért Központ: A blokklánc-technológia és a kriptovaluták müködésének vizsgálata, különös tekintettel a szerződésekérvényességére és a pénzkibocsátás állami monopóliumára (2020. április 14.); A pénzügypiaci decenralizáció hozzájárul a további pénzügyi válságok kibonatkozásához - és így a bizalom csökkenéséhez -, ugyanakkor ironikus módon egyúttal lehetővé teszi a kriptovalutákhoz hasonló pénzügyi fejlesztéseket. Bővebben lásd Nagy Zoltán: A kriptopénzek helye és szerepe a pénzügyi rendszerben. Miskolci Jogi Szemle, 14. (2019), 2. 5-14.

4 A tanulmányban a nagy kezdőbetûvel történő írásmód magát a rendszert, míg a kis kezdőbetủ általában ennek egy pénzügyi egységét jelöli e kriptovaluta esetén.

5 Gábor Tamás - Kiss Gábor Dávid: Bevezetés a kriptovaluták világába. Gazdaság és Pénzügy, 5. (2018), 1. 33-35.
} 
a Bitcoin pénznek tekinthető-e. A tanulmány ezekre a szempontokra igyekszik koncentrálni, miközben átfogó képet mutat a Bitcoin-technológiáról.

\section{A blokklánc koncepciója és alkalmazásai}

A Satoshi Nakamoto által megálmodott hitelesítési rendszer lett a blokklánc, az öszszes kriptovaluta alapja. A blokklánc nem más, mint egy megosztott nyilvántartási könyv, tranzakciókat tartalmazó, decentralizált adatbázis, amelyet nem központilag, hanem számos rendszerben vezetnek és tartanak nyilván. A blokkokra tagolt adatokat saját egyedi azonosítóval is ellátják, amely egy időbélyegből és digitális aláírásból áll. Ezeket a blokkokat kriptográfiai eljárással egymásra fủzik, ahogy újabb és újabb tranzakciókra kerül sor, ezt pedig a rendszer többi résztvevője hitelesíti. Ezek utólag megmásíthatatlanok és visszavonhatatlanok, így garantálják a fizetési rendszer integritását. ${ }^{6} \mathrm{~A}$ harmadik, központi fél hiánya gyors és kis költséggel járó átutalásokat tesz lehetővé. A blokkláncok megváltoztathatatlansága biztosítja az elosztott bizalmat is, mivel szinte lehetetlen megváltoztatni a blokkláncokban tárolt tranzakciókat, és az összes korábbi tranzakció ellenőrizhető és nyomon követhető. ${ }^{7}$

A legelső és azóta is töretlen népszerúségnek örvendő Bitcoin mellett léteznek egyéb kriptopénzek is, ezeket összefoglalóan altcoinoknak nevezik. Ezekből 2020-ra már több mint ötezer létezett, és mind valamilyen egyedi konstrukciót kínál az érdeklődők számára. ${ }^{8}$ Ezeknél két különböző típus különböztethető meg: azok az érmék, amelyek a Bitcoin eredeti, nyílt forráskódú protokollját használják (például a Litecoin) és azon érmék, amelyek a Bitcointól eltérő protokollal működnek (például az Ethereum). ${ }^{9}$ Az altcoinok közé sorolható a blokklánc-technológia másik nagy úttörője, az Ethereum, amely a hitelesítésben részt vevő bányászok számára ether nevü kriptovalutát juttat. Ez a rendszer annyiban másabb, mint a Bitcoin és az annak mintájára megjelent egyéb kriptopénzek, hogy ez más decentralizált eszközök (az úgynevezett „okosszerződések”) számára teremt működési felületet. ${ }^{10}$ Fontos itt még megemlíteni a Monero nevű altcoint is, amely elsősorban a titkosságot helyezi előtérbe. Ennek érdekében érméi teljes egészében helyettesíthetők egymással, ami azt jelenti, hogy szemben a Bitcoinnal, nem lehet bizonyos érméket feketelistára tenni a hozzájuk kötődő korábbi illegális tranzakciók miatt, amelyeket ezeknél az érmeknél a blokklánc örökre megöriz. ${ }^{11}$

\footnotetext{
Gábor-Kiss (2018): i. m. 38.

Zibin Zheng et al.: An Overview on Smart Contracts: Challenges, Advances and Platforms. Future Generation Computer Systems, 37. (2019), 105. 475.

Sam Kopleman: What are altcoins? Everything you need to know. Techradar, 2020. december 23.

9 Robby Houben - Alexander Snyers: Cryptocurrencies and Blockchain. Legal Context and Implications for Financial Crime, Money Laundering and Tax Evasion. European Parliament, 2018. 29.

10 Gábor-Kiss (2018): i. m. 36.

11 Houben-Snyers (2018): i. m. 45.
} 
Azonban a blokklánc-technológiának a lehetséges alkalmazási köre jócskán túlmutat a kriptovalutákon. Alkalmazásának lehetősége egy sor esetben merült már fel, vagy bizonyos esetekben meg is valósították. Így például a közigazgatásban való használata nemcsak a mindennapi papíralapú munkát képes egyszerúsíteni vagy akár teljesen kiváltani, de akár a korrupció csökkenése is várható tőle, ahogy az emberi faktort kikapcsoljuk a folyamatból. Észtország a blokklánc felhasználásával építette ki igen széles körû digitális közigazgatását, de például Szöul önkormányzata is alkalmazza azt. ${ }^{12}$ Ezenkívül hasznosítása felmerül még például az elektronikus szavazás, az egészségügy, az adózás, az ingatlanpiac, az online szerencsejátékok, a biztosítások vagy az élelmiszer-biztonság és logisztika területein is. Elterjedésének korlátját jelentheti azonban az, hogy a rendszer általi validálás önmagában nem az információtartalom valóságát garantálja, hanem kizárólag csak azt, hogy valóban az eredetileg leírtakat rögzítik. ${ }^{13}$

A blokklánc-technológia legérdekesebb hasznosítása mégiscsak a már említett okosszerződések (smart contracts). Ezek alkalmazását először az 1990-es években Nick Szabo vetette fel. Szabo szerint az okosszerződés nem azt jelenti, hogy mesterséges intelligenciát alkalmaznak, csak azt, hogy a számítógépes programban tárolt szerződési feltételeket automatikusan végrehajtják, ha azoknak az előfeltételei megvalósulnak. Ennek a gyakorlati megoldása lett, hogy a tranzakciót blokkláncokban tárolják, replikálják és frissítik, a szerződést pedig automatikusan végrehajtják. Ezzel szemben a hagyományos szerződéseket megbízható harmadik félnek kell centralizált módon teljesítenie, ami hosszú végrehajtási időt és többletköltséget eredményez. ${ }^{14}$ Ennek gyakorlati megvalósulása lehet például a biztosítások terén a síbiztosítás: amennyiben a biztosítás kedvezményezettje elutazik, de az időjárás-jelentések szerint az idő nem kedvez a szolgáltatás igénybevételére, az okosszerződés alapján automatikusan kiutalják neki a biztosító részéről a napidíjat, anélkül, hogy ehhez külön ügyintézésre szükség lenne. Fontos ugyanakkor azt is megjegyezni, hogy a tranzakciók visszafordíthatatlansága kétélű fegyver: ha ugyanis hibásan írják meg, abban az esetben súlyos pénzügyi veszteségekhez vezethet, amelyek visszakönyvelésére már nincs lehetőség. ${ }^{15}$

\section{Fogalmi meghatározás}

A kriptovaluták fogalmi besorolása az egyik olyan kérdés ezen technológiák vizsgálatakor, amely kapcsán rengeteg a vita, ugyanis egyik létező jogi kategóriába sem illeszthető be maradéktalanul.

\footnotetext{
Blockchain: Governing the Government. Asia Blockchain Review, 2019. június 26.

Alapjogokért Központ (2020): i. m.

Zheng et al. (2019): i. m. 475.

Gábor-Kiss (2018): i. m. 36.
} 


\subsection{A pénz fogalma}

$\mathrm{Az}$ egyik legfontosabb és legalapvetőbb kérdés annak eldöntése, hogy pénzről beszélhetünk-e a kriptovaluták esetén. A legelfogadottabb közgazdasági értelemben akkor beszélhetünk fizetőeszközről, ha egy dolog egyszerre felel meg az alábbi három feltételnek: csereeszközként és elszámolási egységként funkcionál, valamint értékhordozó. ${ }^{16} \mathrm{~A}$ pénz fogalmával kapcsolatban azonban vannak eltérő közgazdasági álláspontok is. Akad olyan felfogás, amely elsősorban a csereeszköz-funkció felól közelít, úgy érvelve, hogy bármi tekinthető pénznek, ami általános elfogadott ebben a szerepkörben. Akad felfogás, amely a pénzt a tranzakciós költségek csökkentését lehetôvé tevő innovációként határozza meg, ahol az állam szerepvállalása nem szükséges feltétel, ugyanakkor az államnak el kell ismernie a fizetőeszközt, hogy azt probléma nélkül lehessen használni. ${ }^{17}$

A pénz általános csereeszköz-funkciójában közvetíti az áruk cseréjét, ezáltal könnyítve meg a kereskedelmüket. Elszámolási eszköz funkciójában a pénz mint egység jelenik meg, amely által mérhető a különböző dolgok értéke, és azok ára számszerủleg kifejezhető. Értékhordozó funkciójában pedig tartásának költségei viszonylag alacsonyak kell hogy legyenek, és biztosítania kell az áruk cseréjét. A szakirodalom ezenkívül más funkciókat is ismer. ${ }^{18}$

Jogi értelemben ugyanakkor a három alapvető pénzfunkciónak megfelelő eszközök közül csak az minősül törvényes fizetőeszköznek, amelyet valamely állam központi bankja vagy más monetáris hatósága hozott forgalomba, és afelett felügyeletet gyakorol. Ez a kriptovaluták esetén egyértelműen nem valósul meg, hiszen a blokkláncok mögött egymással egyenlő magánszemélyek hálózata áll, így lényegében teljesen decentralizált a rendszer mind a kibocsátás, mind a tranzakciók terén. ${ }^{19}$ A kriptovaluták nevezhetôk közgazdasági értelemben vett pénznek, ugyanakkor jogilag nem tekinthetők annak - hasonlóan például a videójátékok saját, valódi pénzre váltható fizetőeszközeivel.

\subsection{A kriptovaluták helye a pénzeszközök között}

Ami a kriptopénzek pénzeszközök közötti elhelyezését illeti, a legtágabb kategória a digitális pénzügyi eszközök, ahová minden digitális formában is létező dematerializált eszköz tartozik, így például pénzek, értékpapírok stb. Maguk a központi bankok is kibocsáthatnak ilyen digitális pénzügyi eszközöket. ${ }^{20} \mathrm{~A}$ kategórián belül szűkebb kategóriaként jelennek meg a virtuális pénzek, amelyek csak elektronikus

\footnotetext{
16 Gárdos István: A pénz fogalma. Polgári Jog, 1. (2016), 1. 1-11.

Nagy (2019): i. m. 7.

18 Nagy (2019): i. m. 7-8.

19 Király Péter Bálint: A bitcoin és más kriptovaluták jogi kérdései. In Új Nemzeti Kiválóság Program 2018/2019. Tanulmánykötet. Győr, Széchenyi István Egyetem. 2019. 139.

$20 \quad$ Nagy (2019): i. m. 10.
} 
formában léteznek. Ezekkel kapcsolatosan az Európai Központi Bank (EKB) két fogalommeghatározást is közzétett. A 2012-es meghatározás szerint a virtuális pénz „olyan szabályozatlan digitális pénz, amelyet fejlesztői bocsátanak ki és általában ellenőriznek, és amelyet egy adott virtuális közösség tagjai használnak és fogadnak el”. ${ }^{21}$ 2015-ben az EKB már némileg részletesebben határozta meg a virtuális pénz fogalmát: digitális értékmegjelenés, nem központi bank, hitelintézet vagy epénzintézet bocsátotta ki, és bizonyos körülmények között a pénz alternatívájaként használható. ${ }^{22}$

A kriptopénz ezen belül még szűkebb kategória, amely általános értékmérőés csereeszközszerepet egyaránt betölt, elektronikus fizetőeszközként funkcionál. Az EKB három kategóriára osztotta fel a virtuális pénzeket:

1. csak digitális környezetben használható virtuális pénzek (példáulvideójátékok saját fizetőeszközei);

2. a valós gazdasághoz csak egyoldalúan kötődő virtuális pénzek (például Facebook-kreditek, amelyeket csak megvásárolni és virtuális javakra elkölteni lehet, eladni nem);

3. végül a valós gazdasághoz kétoldalúan kötődő virtuális pénzek (például Bitcoin, amelyet adni és venni is lehet, és mind virtuális, mind valós javakra elkölthető).

A későbbi meghatározás egyértelműsítette is a kriptovaluták besorolását, mint bilaterális virtuális fizetőeszközök. ${ }^{23}$

A Nemzetközi Fizetések Bankja (BIS) alá tartozó Fizetési és Piaci Infrastruktúra Bizottság meghatározása szerint a kriptovaluták a digitális pénzek közé sorolhatók, és három lényegi jellemzőjük van. Ezek:

- olyan eszközök, amelyek értékét a kínálat és a kereslet határozza meg, koncepciójukban hasonlatosak az olyan árukhoz, mint az arany, de nem rendelkeznek önálló értékkel;

- elosztott főkönyveket alkalmaznak, hogy lehetővé tegyék az elektronikus érték távoli cseréjét a felek közötti bizalom és közvetítők szükségessége nélkül;

- és nem valamely személy vagy intézmény múködteti. ${ }^{24}$

Az Európai Bankhatóság meghatározása szerint a kriptovaluta „valamilyen érték digitális megjelenése, amelyet nem központi bank vagy hatóság bocsátott is, nem feltétlenül kapcsolódik törvényes fizetőeszközhöz, de amelyet természetes vagy jogi személyek elfogadnak fizetőeszközként, és amely elektronikus úton átadható, tárolható vagy kereskedhető". ${ }^{25}$

\footnotetext{
Európai Központi Bank: Virtual Currency Schemes (2012).

Európai Központi Bank: Virtual Currency Schemes (2015). 9.

Houben-Snyers (2018): i. m. 20.

Nemzetközi Fizetések Bankja: Digital currencies (2015). 4-7.

Európai Bankhatóság: EBA Opinion on 'virtual currencies' (2014. július 4.).
} 
A kriptovaluta nem keverendő össze az elektronikus pénz fogalmával, a kettő ugyanis nem szinonim. Az elektronikus pénz az EU fogalmi meghatározása szerint „a kibocsátóval szembeni követelés által megtestesített, elektronikusan tárolt - ideértve a mágneses tárolást is - monetáris érték, amelyet pénzeszköz átvételével bocsátanak ki, [...] és amelyet az elektronikuspénz-kibocsátón kívül más természetes vagy jogi személy is elfogad”. ${ }^{26}$ Külön irányelv határozza meg a pénz általában vett fogalmát is, amelybe „bankjegyek és pénzérmék, számlapénz, vagy elektronikus pénz" tartoznak. ${ }^{27} \mathrm{Az}$ EU-irányelv szerinti fogalomnak a kriptovaluta nem felel meg, hiszen kibocsátására nem valamilyen pénzeszköz átvételével kerül sor.

A Bitcoin azonban nem tekinthető általános értelemben vett elektronikus pénznek, hiszen nincs kibocsátója, semmilyen szervezet nem gyakorol felügyeletet felette, és nem áll mögötte semmilyen vagyoni fedezet. ${ }^{28}$

\subsection{A kriptovaluták fogalmi elhelyezése}

Mindezek alapján nagy nehézségbe ütközik az, aki megpróbálja a kriptovaluták jogi fogalmát meghatározni. A korábbiakban említett példákban általában nem kerül sor külön fogalom megalkotására, csak egy nagyobb rendszerben való elhelyezésére, valamilyen egyedi jellemzője alapján. Ez alapján kimondhatjuk, hogy a kriptovaluta a digitális pénzeszközök és azon belül is a virtuális pénzek kategóriájába tartozik. A Houben-Snyers szerzőpáros a korábban ismertetett, illetve itt külön nem ismertetett fogalommeghatározási kísérletek alapján a következő közös elemeket gyűjtötte össze:

„Valamilyen érték digitális megjelenése, ami

1. a kormány által kibocsátott törvényes fizetőeszköz peer-to-peer (P2P) alternatívájaként hivatott,

2. általános célú csereeszközként használják (függetlenül bármilyen központi banktól),

3. a kriptográfia néven ismert mechanizmus biztosítja múködését, valamint

4. törvényes fizetőeszközre váltható és fordítva." ${ }^{29}$

A kriptovaluták valamilyen pénzeszközként való meghatározása ugyan népszerű megközelítés, de korántsem kizárólagos. Az egyértelműen pénzként való besorolás

26 Az Európai Parlament és a Tanács 2009/110/EK irányelv (2009. szeptember 16.) az elektronikuspénz-kibocsátó intézmények tevékenységének megkezdéséről, folytatásáról és prudenciális felügyeletéről, a 2005/60/EK és a 2006/48/EK irányelv módosításáról, valamint a 2000/46/EK irányelv hatályon kívül helyezéséről [HL L 267, 10.10.2009, 7-17.] 2. cikkének 2. pontja.

27 Az Európai Parlament és a Tanács (EU) 2015/2366 irányelv (2015. november 25.) a belső piaci pénzforgalmi szolgáltatásokról és a 2002/65/EK, a 2009/110/EK és a 2013/36/EU irányelv és a 1093/2010/EU rendelet módosításáról, valamint a 2007/64/EK irányelv hatályon kívül helyezéséről [HL L 337, 23.12.2015, 35-127.] 4. cikkének 25. pontja.

28 Lakatos Alexandra Anna: Az informatikai bűncselekmények és a bitcoin. Belügyi Szemle, 65. (2017), 1. 29-30.

29 Houben-Snyers (2018): i. m. 23. 
elsősorban az Egyesült Államokban - csak bizonyos korlátozott esetekben, például a törvényes fizetőeszközre történő átváltás során - vált uralkodó nézetté. A legtöbb ország ugyanakkor vonakodik elismerni a kriptovalutát mint törvényes fizetőeszközt, pontosan az arra való hivatkozással, hogy azt nem valamely állam bocsátotta ki, és egyetlen központi bank sem gyakorol felette felügyeletet. Egy némileg népszerübb elképzelés elismeri, hogy a kriptovaluták pénzként viselkednek, de csak készpénz-helyettesítő eszközökként tekint rájuk. ${ }^{30}$ Jogi értelemben azonban ez is nehezen támasztható alá: a készpénz-helyettesítő eszközök általában fizikai formában is léteznek, például csekként vagy más formában - mint utalvány vagy kártya -, de még az idesorolt elektronikus pénz fogalmába sem illeszthető be a kriptovaluta (mint azt már láttuk). ${ }^{31}$

A következő lehetséges jogi minősítés az értékpapír. Bár a tokenek - később részletesebben lesz szó róluk - magukban hordozzák a részvény bizonyos ismérveit, annak kibocsátására csak részvénytársaságok jogosultak. Ugyanígy felmerült a kriptovaluták vagyoni értékű jogként, illetve árucikként vagy tulajdonként való minősítésének lehetősége, ám ezek mindegyike tévútnak ígérkezett. ${ }^{32}$ Utóbbi kettő különösen azért lehet népszerú, mert megnyitja az utat a kriptovaluták megadóztatása elótt, ${ }^{33}$ ám dogmatikai szempontból nehezen indokolható meg, hogy egy egyértelműen fizetőeszközként létrehozott eszköz miként lenne árucikknek tekinthető, hiszen nem azért, hanem pontosan, hogy azzal fizetnek az online tranzakciókban más javakért. Az árucikként való minősítés mellett szól azonban az az érv, hogy a Bitcoin esetén a maximálisan forgalomba hozható mennyiség véges. Ilyen felső korlát pénzeszköz esetén nem létezik. ${ }^{34}$

Mindezek alapján tehát látható, hogy ha a múködése alapján létrehozható olyan fogalom, amely alá tartozhat, a jogi besorolása bármely kategóriába szinte lehetetlen vállalkozásnak tűnik. A legtöbb jogrendszerben éppen ezért nem is került sor a kategorizálására, és jobb esetben csak eltûrt eszköznek számít, rosszabb esetben teljes egészében betiltják.

\section{A kriptovaluták múködése}

\subsection{A kriptovaluták jellemzói}

A kriptovalutáknak számos olyan jellemzője van, amelyek a technológiai alapjaikból következnek és kihatással vannak az alkalmazásukra, különösen az illegális célra

30 Irina Cvetkova: Cryptocurrencies Legal Regulation. Brics Law Journal, 5. (2018), 2. 133.

31 Ezzel kapcsolatosan lásd az MNB kapcsolódó állásfoglalását: Magyar Nemzeti Bank: Bitcoin automata müködtetésének, üzemeltetésének jogi megitélése (2017).

32 Pfeffer Zsolt: A fizetésre használható virtuális eszközök. Kodifikáció és Közigazgatás, 6. (2017), 1. 22.

33 Cvetkova (2018): i. m. 136.

34 Fiammetta Piazza: Bitcoin in the Dark Web: A Shadow over Banking Secrecy and a Call for Global Response. Southern California Interdisciplinary Law Journal, 26. (2017), 3. 529. 
való felhasználásra. Ebben a fejezetben áttekintjük ezeket az alapvető vonásokat és azok jogi következményeit is.

\subsubsection{Anonimitás}

Az anonimitás - vagy sok esetben inkább csak pszeudonimitás - a kriptovaluták egyik legfontosabb jellemzője, elvégre az érme nem névre szól, egy személy se kapcsolható közvetlenül valamely tárcához vagy tranzakcióhoz. Csak az dönti el a kriptovaluta használhatóságát, hogy ki van az ehhez szükséges titkosítási kulcs birtokában, miközben egyúttal az utolsó azzal végzett tranzakció címzettjeként jegyezték be az adott érméhez tartozó blokkláncban. Az anonimitás foka az egyes kriptovalutáknál jelentősen eltérhet. A korábban már említett Monero esetén például az összes tranzakció teljesen rejtve van a kriptográfia mögött, ami egyaránt titkosítja a feladó és címzett feleket, valamint az átutalt összegeket. ${ }^{35}$ Ezzel szemben a Bitcoinnál a főkönyv szabadon nézegethető, elemezhető, az egyes érmékhez tartozó blokklánc annak kibányászásáig visszakövethető.

Ugyan a Bitcoin esetén az egyes érmék felhasználói alapvetően teljesen ismeretlenek, azonban a címek közötti utalások iránya, azok ideje és nagysága mindenki számára látható. Ez azt jelenti, hogy ha a láncolatban sikerül valakit azonosítani, akkor onnantól kezdve a teljes utalástörténete visszakövethetővé válik. Ennek elkerülésére léteznek úgynevezett mixing szolgáltatások, amelyeknek a lényege, hogy számos felhasználó tranzakcióját összesítik, ezáltal követhetetlenné téve a valós láncolatot, ugyanakkor az láthatóvá válik, hogy valaki ezt az eszközt igénybe vette. ${ }^{36}$

A mixing szolgáltatások igénybevétele mellett fontos megemlíteni azt is, hogy a kriptovaluták egymás közötti váltása is képes lehet arra, hogy a visszakövethetőséget lehetetlenné tegye. Ez különösen igaz, ha figyelembe vesszük, hogy az ezzel foglalkozó kriptotőzsdék és kriptováltók gyakran kevéssé szabályozott országokban vagy több joghatóság alatt működnek. A problémát tovább növeli az, hogy a felhasználók egymás között is közvetlenül cserélgethetik érméiket, bármiféle közvetítő bevonása nélkül (úgynevezett atomic swap). ${ }^{37}$

$\mathrm{Az}$ anonimitás jogi következményei elég egyértelműek. Lehetetlenné teszi a hatóságok számára, hogy megfelelően monitorozzák a kriptovaluták mozgását, ezáltal lehetőséget nyit arra, hogy azt illegális célokra használják. Ez nem feltétlenül bűncselekményt takar, lehet például adóelkerülés érdekében elrejteni vagyont, kriptopénzbe történő befektetéssel. Akad olyan vélekedés, amely a kriptopénzeket egyenesen a ,jövő adóparadicsomai"-ként aposztrofálja. ${ }^{38}$

\footnotetext{
35 Mezei Kitti: A kriptovaluták kihívásai a büntető anyagi és eljárási jogban. Pro Futuro, 9. (2019), 1. 83.

36 Fedor Poskriakov - Maria Chiriaeva - Christophe Cavin: Cryptocurrency Compliance and Risks: A European KYC/AMLP Perspective. In Josias N. Dewey (szerk.): Blockchain \& Cryptocurrency Regulation. Global Legal Group, 2019. 162-173.

37 Poskriakov-Chiriaeva-Cavin (2019): i. m.

38 Houben-Snyers (2018): i. m. 53.
} 


\subsubsection{Decentralizáció}

A másik fontos jellemző a decentralizáltság, a kriptopénzek működési elvéből ered: nincs mögötte olyan állami központi bank, amely kibocsátaná azt, illetve felügyeletet gyakorolna. Minden tranzakció egy peer-to-peer rendszerben történik, ahol a résztvevők maguk hitelesítik a tranzakciókat. Így nincs olyan központi szerv, amelyhez fordulni lehetne adatigénylés vagy lefoglalás érdekében. A decentralizáltság azt is jelenti, hogy mindig az adott állam törvényei vonatkoznak a különböző kapcsolódó szolgáltatást nyújtókra. Ez a gyakorlatban oda vezethet, hogy a rosszindulatú résztvevők megpróbálnak olyan joghatóság alatt múködni, amely egyáltalán nem, vagy csak kevéssé szabályozza a kriptovalutákkal kapcsolatos kérdéseket, visszaéléseket. ${ }^{39} \mathrm{Ez}$ a határokon átnyúló jelleg azt is jelenti, hogy kizárólag nemzeti szinten nem lehet eredményesen felvenni a harcot a kriptovalutákhoz kapcsolódó negatív jelenségekkel. ${ }^{40}$

\subsubsection{Bizalom}

A bizalom alapja a bizonytalanság: bizonyosan bekövetkező dolgok esetén (például reggel felkel a Nap) szükségtelen tényező a bizalom. A bizalom a gazdasági tevékenység egyik legfontosabb alapja, ez különösen igaz olyan esetben, ha az üzleti tevékenység kizárólag online történik. A kriptovaluták esetén a bizalom legfontosabb - és talán egyetlen - alapja az a matematikai algoritmus, amely az adott kriptovalutát létrehozta: ez a blokklánc. A Bitcoin és más kriptovaluták arra az elképzelésre épülnek, hogy a bizalmat nem igénylő rendszerek minden szempontból felette állnak a bizalmat igénylő rendszereknek. ${ }^{41}$ Kutatások szerint elterjedésének pontosan az kedvez igazán, hogy nő az általános bizalmatlanság a bankok múködésével kapcsolatban. ${ }^{42}$

A blokklánc-technológia sajátossága abban áll, hogy csökkenti a bizalom iránti igényt, hiszen itt nem szükséges egyénekben vagy közvetítőkben megbízni ahhoz, hogy pénzügyi eszközként használható legyen. Ezt a bizalmi szerepet ugyanis átveszi az algoritmus. Maga a Bitcoin kitalálója, Satoshi Nakamoto is úgy fogalmazott javaslatában, hogy „az elektronikus tranzakciók egy rendszerét javasoljuk, a bizalomra való hagyatkozás nélkül” ${ }^{43}$

Bár a bizalom jelen esetben nem szükséges a Bitcoin mint technikai megoldás használatához, a tapasztalatok azt mutatják, hogy mégis megjelenik valamilyen

\footnotetext{
39 Poskriakov-Chiriaeva-Cavin (2019): i. m.

40 Houben-Snyers (2018): i. m. 53.

41 Catherine Martin Christopher: The Bridging Model: Exploring the Roles of Trust and Enforcement in Banking, Bitcoin, and the Blockchain. Nevada Law Journal, 17. (2016), 1. 155-158.

42 Ed Saiedi - Anders Broström - Felipe Ruiz: Global Drivers of Cryptocurrency Infrastructure Adoption. Small Business Economics, 57. (2020), 1. 355.

43 Satoshi Nakamoto: Bitcoin: A Peer-to-Peer Electronic Cash System. 2008. 8.
} 
formában. Ez pedig a kriptovaluták rendkívül erős volatilitásához kapcsolódik. A magas árfolyam-ingadozás a Bitcoin-piac erősen spekulatív jellegének eredménye. Kutatások szerint széles körben elfogadott alapvetés, hogy a legtöbb Bitcointranzakcióra spekulatív szereplők között kerül sor. Ezért észszerűnek tűnik feltételezni, hogy a Bitcoinok vásárlásához szükség van bizonyos szintű kockázatvállalási hajlandóságra. A pénzügyi kockázatok vállalásának átlagos hajlandóságában rejlő regionális különbségek ezért erősen befolyásolhatják a Bitcoin használatát és elterjedtségét. ${ }^{44}$

\subsection{A tokenek és kibocsátásuk}

A kriptovaluták legfontosabb része a már említett, törzskönyvként funkcionáló blokklánc. Ehhez bizonyos tokenek kapcsolódnak, amelyek nyilvántartását és könyvelését a blokklánc végzi, másrészt ezek pénzügyi ösztönzőként is hatnak a blokklánc működésében való részvételre, hiszen jutalmul ezeket „bányásszák ki”. A Bitcoin rendszerén belül ilyen token lehet a bitcoin, míg az Ethereum esetén az ether. A tokeneknek három fajtáját különböztethetjük meg:

- utility token,

- security token, valamint

- kriptovaluta-token.

Ezek különböző funkciókat töltenek be. Egy token akár a fenti három kategória tulajdonságait is vegyítheti magában. A utility token olyan szolgáltatáshoz vagy termékhez való hozzáférés jogát jelenti, amely csak a jövőben fog létrejönni. Amenynyiben egy token tisztán utility jellegú, úgy gyakorlatilag csak egyszer használatos, és megszűnik a felhasználáskor (vagy angol terminológia szerint „elég” - burn). A security token gyakorlatilag részvényhez hasonló jogosultságokat ad, például szavazati jogot az adott blokklánc kapcsán hozott közösségi döntésekben. Végezetül pedig vannak a kriptovaluta-tokenek, amelyek virtuális pénzek, a hitelesítés ellenértékeként, bányászattal jönnek létre, és fizetőeszközként elfogadják az adott blokklánc felhasználói. ${ }^{45}$

Ami a tokenek kibocsátását illeti, akadnak olyan blokkláncok, ahol ez folyamatosan történik, és a hitelesítésben részt vevők ellenértékként kapják meg azt. Ezeknél kétféle típus létezik: ahol korlátlan mennyiségű kriptovaluta hozható forgalomba, és olyan, ahol előre meghatározzák a forgalomba hozható tokenek felső korlátját (például a Bitcoin is ilyen). Léteznek ugyanakkor olyan blokkláncok, ahol a kriptovaluta mennyiségét előre meghatározták és kibocsátották, és annak mennyisége ezt követően nem változik. Ilyen esetben a hitelesítésben részt vevő felhasználók

\footnotetext{
44 Saiedi-Broström-Ruiz (2020): i. m. 355.

45 Király (2019): i. m. 136.
} 
a tranzakciók után fizetett tranzakciós díjat kapják meg jutalom gyanánt. A kriptovaluták önmagukban nem jelentenek értéket, azt csak az adja nekik, hogy a blokklánc felhasználói elfogadják azt fizetségként. ${ }^{46}$

A security és utility tokenek esetén okosszerződésben rögzítik azt, hogy pontosan milyen jogokat is juttatnak a tulajdonosaik számára. Ezek a tokenek már önmagukban is képviselnek pénzügyi értéket, hiszen valamilyen jogosultságot jelenítenek meg. Ezek forgalomba hozatalának a módja az elsődleges érmekibocsátás (initial coin offering, ICO), amely hasonló az induló részvénytársaságok nyílt részvénykibocsátással történő tőkebevonásához, de egyúttal a közösségi finanszírozás (crowdfunding) egyik sajátos formája is. Ekkor az új kriptopénzt első alkalommal kínálják eladásra, törvényes fizetőeszköz vagy más, általánosan bevett kriptovaluta ellenében lehet jegyezni még azt megelőzően, hogy ahhoz kriptotőzsdén vagy bármelyik kriptováltóban hozzá lehetne jutni. ${ }^{47}$ Ezáltal a kibocsátó pénzhez jut a terve megvalósítása érdekében, míg a befektető később előnyöket szerez a termék megjelenésekor. Ugyanakkor ez a módszer számos visszaélésére is okot ad, és a legtöbb nemzeti bank, illetve hatóság óva inti az embereket tőle.

Ami a tokenek jogi megítélését illeti, legalább olyan zavaros a helyzet, mint maguknál a különböző kriptovalutáknál. Korábban már említettem, hogy a részvényekhez hasonló módon múködnek az utilty és security tokenek. Ennek jogi megalapozottságát vizsgálta az Amerikai Értékpapír- és Tőzsdefelügyelet, amely az úgynevezett Howey-tesztet alkalmazta a kérdés eldöntésére. A teszt szerint az számít értékpapírnak, ahol pénzt fektetnek be, a befektetőt a profitszerzés vágya hajtja, a befektetés egy közös vállalkozásba történik, és a profit harmadik személyek vagy támogatók tevékenységéből származik. A felügyelet arra jutott, hogy az említett két tokenfajta megfelel ezeknek a követelményeknek, hiszen, ha a későbbi eladás a cél a vásárláskor, akkor az első két feltételnek máris megfelelt. A közös vállalkozás (az új kriptovaluta) sikere minden résztvevő számára fontos, ahhoz anyagi érdeke kapcsolódik, míg, ha a hitelesítésben részt vevő „bányászokra” úgy tekintünk, mint akiknek a tevékenységéből a profit származik, azzal az utolsó feltételnek is megfeleltethető. ${ }^{48}$

\subsection{A kriptopiac résztvevối}

A kriptovaluták piaca megteremtette saját résztvevőit, akik más-más céllal vannak jelen a rendszerben. Egy szereplő akár több szerepkörben is jelen lehet a rendszerben, ugyanakkor az is könnyen elképzelhető, hogy valakit csak egy-egy aspektusa érdekli a kriptovalutáknak.

\footnotetext{
46 Király (2019): i. m. 137.

47 Györfi András: Az ICO - Így indul útjára egy kriptopénz. In Györfi András. (szerk.): Kriptopénz ABC. Budapest, HVGORAC, 2019. 102.

48 Király (2019): i. m. 139-140.
} 
A legelső csoport a felhasználóké, akik lehetnek természetes és jogi személyek egyaránt, akik szert tesznek egy adott kriptovalutára abból a célból, hogy azzal valós vagy virtuális javakat, illetve szolgáltatásokat vásároljanak, tranzakciókat indítsanak, vagy pedig befektetési célra - spekulatívan - birtokolják. A kriptovaluták legális megszerzésére számos lehetőség van (bár ezek eltérhetnek a konkrét kriptopénztől függően):

- annak megvásárlása kriptováltótól törvényes fizetőeszköz vagy más kriptovaluta segítségével, de a vásárlás történhet más felhasználótól is;

- bányászással (a tranzakciók hitelesítésének segítségével);

- az adott érme kibocsátójától, például elsődleges érmekibocsátás során;

- javak vagy szolgáltatások kriptovalutáért történő eladásával;

- „hard fork”" ${ }^{\prime 2}$ idején a kriptopénz minden aktuális tulajdonosa részesülni fog az újonnan létrehozott érméböl; és végül

- ajándékként vagy felajánlással is hozzájuthat más felhasználóktól. ${ }^{50}$

A következő fontos résztvevői csoport a bányászoké, akik a tranzakciók hitelesítését végzik, és cserébe az adott érméből kompenzálják őket (már amennyiben ezt a kérdéses kriptovaluta engedélyezi). A bányászok lehetnek egyszerű felhasználók, de olyanok is, akik üzleti célból vesznek részt a bányászásban és nem saját használatra használják a kitermelt érméket, hanem eladják azokat törvényes fizetőeszközökért cserébe. Egyes bányászok úgynevezett bányászcsoportokba tömörülnek, hogy a számítási teljesítményt összekapcsolják. ${ }^{51}$ A tranzakciók hitelesítésére általában a résztvevők 51\%-ra van szükség, és a kompenzációt a felhasznált erőforrás mértéke szerint kalkulálják ki. ${ }^{52}$

Fontos szerepet töltenek be a tőzsdei szolgáltatást nyújtó kriptovaluta-tôzsdék és-átváltók, akik lehetnek természetes és jogi személyek egyaránt, tevékenységüket pedig általában valamilyen jutalék ellenében lehet igénybe venni. A kriptovalutatőzsdék jellemzően váltóként is üzemelnek, ám ez fordítva már nem igaz. ${ }^{53}$ Fontos megjegyezni, hogy a tőzsdék átváltószolgáltatást is nyújtanak. Ennek során múködhetnek „tiszta kriptovaluta-tőzsdeként”, ami azt jelenti, hogy csak más kriptovalutákban fogadnak el fizetéseket - általában Bitcoinban (például a Binance) -, míg mások „rendes kriptovaluta-tőzsdeként” hivatalos fizetőeszközökben, például amerikai dollárban vagy euróban is (például a Coinbase). Számos kriptotőzsde csak bizonyos érmék megvásárlását teszi lehetővé a felhasználók számára. Azt is meg kell jegyezni, hogy sok kriptotőzsde letétkezelő pénztárca-szolgáltatóként múködik

\footnotetext{
49 A fork jelen esetben elágazódást jelent, és akkor használatos kifejezés, ha egy blokkláncból többen kiválnak, és új blokkláncon folytatják a bányászást. Ekkor a korábbi közösség egyik fele képletesen a korábbi utat követi tovább, míg a többiek letérnek egy elágazódásnál. Ez akkor történhet meg, ha a közösség egy része frissíteni akar a meglévő szoftveren, ám a többi résztvevő ezt nem támogatja. Ilyen eset volt például a Bitcoin Cash kiválása a Bitcoinból.

50 Houben-Snyers (2018): i. m. 25.

51 Houben-Snyers (2018): i. m. 25-26.

Mezei (2019): i. m. 81.

53 Mezei (2019): i. m. 82.
} 
(például Bitfinex). Általában a fizetési lehetőségek széles választéka áll a felhasználóik rendelkezésére, például átutalás, PayPal-átutalás, hitelkártyák és egyéb érmék. Néhányan statisztikákat is szolgáltatnak a kriptovaluta-piacról (például a kereskedelem volumene és az érme volatilitása vonatkozásában), és konverziós szolgáltatásokat kínálnak azon kereskedők számára, akik kriptovalutában is elfogadnak fizetséget. $^{54}$

Az úgynevezett „kereskedelmi platformok” is fontos szerepet játszanak a kriptovaluták cseréjében (és főleg lehetővé teszik a felhasználók számára, hogy érméket vásárolhassanak). A kereskedelmi platformok olyan piacok, amelyek különböző felhasználókat hoznak össze, akik érméket akarnak vásárolni vagy eladni, és olyan platformot biztosítanak számukra, amelyen keresztül közvetlenül egymással kereskedhetnek. Ezek számos szempontból különböznek a kriptovaluta-tőzsdéktől. Először is a legfontosabb, hogy ők maguk nem vásárolnak vagy nem adnak el érméket, csak az érdeklődő felhasználókat kötik össze. Másodszor, nem egy olyan szervezet vagy vállalat múködteti őket, amely az összes kereskedelmet felügyeli és feldolgozza, hanem csak és kizárólag szoftverek. A kereskedelmi platformok egyszerűen összekapcsolják a vevőt az eladóval, lehetővé téve számukra az ügyletkötés online vagy akár helyben, személyesen történő lebonyolítását - azaz a személyes kereskedést, amelyet gyakran készpénzben hajtanak végre. ${ }^{55}$

Fontos szerepet játszanak még a kriptogazdaságban a „pénztárca-szolgáltatók”. A pénztárca-szolgáltatók a felhasználók számára nyújtanak digitális vagy epénztárcákat, amelyeket érmék tárolására és átadására használnak. Egyszerủen fogalmazva: a pénztárca egy kriptopénz-felhasználó kriptográfiai kulcsait tartalmazza - hasonlóan a való világbeli pénztárcához gyakorlatilag a tárolást szolgálja. A digitális pénztárca különböző kriptopénznemeket tárolhat, küldhet és fogadhat, így alapvető feltétele a kriptopénzekkel történő tranzakcióknak.

A pénztárca-szolgáltató általában a kriptovaluta-felhasználó tranzakcióit könynyen olvasható formátumra fordítja, amely hasonlít egy szokásos, átlagos bankszámlára. A valóságban a pénztárca-szolgáltatóknak több típusa létezik, amelyek felosztása kissé eltér az előző címben foglaltaktól. Az ilyen szolgáltatók lehetnek:

- hardveres pénztárca-szolgáltatók, amelyek a felhasználók számára speciális hardveres megoldásokat kínálnak, privát módon tárolják kriptográfiai kulcsaikat;

- szoftveres pénztárca-szolgáltatók, amelyek a felhasználók számára olyan szoftveralkalmazásokat biztosítanak, amelyek lehetővé teszik számukra a hálózat elérését, érmék küldését és fogadását, valamint a kriptográfiai kulcsok helyi mentését (például Jaxx);

- letétkezelő pénztárca-szolgáltatók, amelyek (online) őrzik a kriptovalutafelhasználó kriptográfiai kulcsait. ${ }^{56}$ 


\section{6. Összefoglalás}

A tanulmányban betekintést nyerhettünk a kriptovalutákkal kapcsolatos legfontosabb kérdésekbe. A 2008-ban megálmodott fizetési rendszer közvetlen válasz volt az évtized nagy pénzügyi válságára, célja pedig a közvetítő kiszorítása volt a tranzakciókból. Ehhez egy olyan decentralizáltan és anonim módon múködő rendszert alkottak meg, amely kizárta a bizalmi faktort a működéséből, még ha az közvetetten jelen is van a használata során. Egyrészt a nagy árfolyam-ingadozásra való tekintettel, másrészt pedig negatív formában, a bankrendszer iránti bizalmatlanság eredményeként. Azon országokban, ahol nagyobb ez utóbbinak a mértéke, és magasabb a kockázatvállalási hajlandóság, jobban elterjedt a fizetési módszer.

A Bitcoin mellett számos altcoin is létezik, ám a legelső kriptovaluta még mindig a legnépszerúbbnek is számít. A fizetési rendszer sikerét mutatja szélesebb körű elterjedtsége, a vele kapcsolatba hozható számos szereplő, a kereskedelmi platformoktól kezdve a kriptotőzsdéken át a pénztárca-szolgáltatókig terjedő skálán igen széles választék várja a kriptovalutában érdekelt felhasználókat.

Szembetűnő, hogy a széles elterjedtség mellett a kapcsolódó jogi szabályozás mennyire lemaradt. Mint annyiszor máskor, a technológiai fejlődés most is előtte jár a társadaloménak. Ez a jelenség nemcsak a kriptovalutákra igaz, hanem a szélesebb pénzügyi szektort is érinti, és további probléma, hogy míg a kihívás globális, a megoldások pusztán lokálisak. ${ }^{57}$ A kriptovaluták jogi meghatározása már önmagában komoly nehézségekbe ütközik, hiszen az egyetlen már létező jogi kategóriának se feleltethető meg maradéktalanul. Az egyéb fogalmi meghatározások is komolyabb akadályokba ütköznek. Mindezen tényezők előrevetítik, hogy a spekulatív befektetések mellett a kriptovaluták másik nagy felhasználási területe a bűnözés, amely aspektusról a következő tanulmányok szólni fognak.

\section{IRODALOMJEGYZÉK}

Alapjogokért Központ: A blokklánc-technológia és a kriptovaluták müködésének vizsgálata, különös tekintettel a szerződések érvényességére és a pénzkibocsátás állami monopóliumára (2020. április 14.). Online: http://alapjogokert.hu/2020/04/14/a-blokklanc-technologia-es-a-kriptovalutakmukodesenek-vizsgalata/

Blockchain: Governing the Government. Asia Blockchain Review, 2019. június 26. Online: www. asiablockchainreview.com/blockchain-governing-the-government/

Christopher, Catherine Martin: The Bridging Model: Exploring the Roles of Trust and Enforcement in Banking, Bitcoin, and the Blockchain. Nevada Law Journal, 17. (2016), 1. 139-180. Online: https://scholars.law.unlv.edu/cgi/viewcontent.cgi?referer=\&httpsredir=1\&article=1694\&context=nlj

Cvetkova, Irina: Cryptocurrencies Legal Regulation. Brics Law Journal, 5. (2018), 2. 128-153. Online: https://doi.org/10.21684/2412-2343-2018-5-2-128-153

57 Nagy Zoltán: A digitalizáció hatása a pénzügyi piac szabályozására. Miskolci Jogi Szemle, 15. (2020), 1. 30. 
Európai Bankhatóság: EBA Opinion on 'virtual currencies' (2014. július 4.). Online: https://eba. europa.eu/sites/default/documents/files/documents/10180/657547/81409b94-4222-45d7ba3b-7deb5863ab57/EBA-Op-2014-08\%20Opinion\%20on\%20Virtual\%20Currencies.pdf?retry $=1$

Európai Központi Bank: Virtual Currency Schemes (2012). Online: www.ecb.europa.eu/pub/pdf/ other/virtualcurrencyschemes201210en.pdf

Európai Központi Bank: Virtual Currency Schemes (2015). Online: www.ecb.europa.eu/pub/pdf/ other/virtualcurrencyschemesen.pdf

Gábor Tamás - Kiss Gábor Dávid: Bevezetés a kriptovaluták világába. Gazdaság és Pénzügy, 5. (2018), 1. 31-65. Online: www.bankszovetseg.hu/Public/gep/2018/031-65g\%20GaborKiss.pdf

Gárdos István: A pénz fogalma. Polgári Jog, 1. (2016), 1. 1-11. Online: https://gmtlegal.hu/cikkek/ a-penz-fogalma.php?kid=4\&did=273

Györfi András: Az ICO - Így indul útjára egy kriptopénz. In Györfi András. (szerk.): Kriptopénz ABC. Budapest, HVG-ORAC, 2019. 101-117.

Houben, Robby - Alexander Snyers: Cryptocurrencies and blockchain. Legal context and implications for financial crime, money laundering and tax evasion. European Parliament, 2018. Online: www.europarl.europa.eu/cmsdata/150761/TAX3\%20Study\%20on\%20cryptocurrencies\%20 and\%20blockchain.pdf

Király Péter Bálint: A bitcoin és más kriptovaluták jogi kérdései. In Új Nemzeti Kiválóság Program 2018/2019. Tanulmánykötet. Győr, Széchenyi István Egyetem. 2019. 135-144. Online: https://tud.sze.hu/images/\%C3\%9ANKP/2018-2019/tanulm\%C3\%A1nyk\%C3\%B6tet/Kir\%C3\%A1ly\%20P\%C3\%A9ter\%20B\%C3\%A1lint.pdf

Kopleman, Sam: What are altcoins? Everything you need to know. Techradar, 2020. december 23. Online: www.techradar.com/news/what-are-altcoins-everything-you-need-to-know

Lakatos Alexandra Anna: Az informatikai büncselekmények és a bitcoin. Belügyi Szemle, 65. (2017), 1. 24-44. Online: https://doi.org/10.38146/BSZ.2017.1.2

Magyar Nemzeti Bank: Bitcoin automata müködtetésének, üzemeltetésének jogi megitélése (2017). Online: http://alk.mnb.hu/data/cms2453595/tmp6044.tmp(14438466).pdf

Mezei Kitti: A kriptovaluták kihívásai a büntető anyagi és eljárási jogban. Pro Futuro, 9. (2019), 1. 79-98. Online: https://doi.org/10.26521/Profuturo/1/2019/3906

Nagy Zoltán: A kriptopénzek helye és szerepe a pénzügyi rendszerben. Miskolci Jogi Szemle, 14. (2019), 2. 5-14. Online: www.mjsz.uni-miskolc.hu/files/7900/3_nagyzolt\%C3\%A1n_t\%C3\%B6rdelt.pdf

Nagy Zoltán: A digitalizáció hatása a pénzügyi piac szabályozására. Miskolci Jogi Szemle, 15. (2020), 1. 24-32. Online: www.mjsz.uni-miskolc.hu/files/10854/4_nagyzoltan_t\%C3\%B6rdelt.pdf

Nakamoto, Satoshi: Bitcoin: A Peer-to-Peer Electronic Cash System. 2008. Online: https://perma. cc/3KWX-L8FE

Nemzetközi Fizetések Bankja: Digital currencies (2015). Online: www.bis.org/cpmi/publ/d137.pdf Pfeffer Zsolt: A fizetésre használható virtuális eszközök. Kodifikáció és Közigazgatás, 6. (2017), 1. 16-27.

Piazza, Fiammetta: Bitcoin in the Dark Web: A Shadow over Banking Secrecy and a Call for Global Response. Southern California Interdisciplinary Law Journal, 26. (2017), 3. 521-546. Online: https://mylaw2.usc.edu/why/students/orgs/ilj/assets/docs/26-3-Piazza.pdf

Poskriakov, Fedor - Maria Chiriaeva - Christophe Cavin: Cryptocurrency Compliance and Risks: A European KYC/AMLP Perspective. In Josias N. Dewey (szerk.): Blockchain \& Cryptocurrency Regulation. Global Legal Group, 2019. 162-173. Online: www.acc.com/sites/default/files/resources/vl/membersonly/Article/1489775_1.pdf

Saiedi, Ed - Anders Broström - Felipe Ruiz: Global Drivers of Cryptocurrency Infrastructure Adoption. Small Business Economics, 57. (2020), 1. 353-406. Online: https://doi.org/10.1007/ s11187-019-00309-8 
Zheng, Zibin - Shaoan Xie - Hong-Ning Dai - Weili Chen - Xiangping Chen - Jian Weng - Muhammad Imran: An Overview on Smart Contracts: Challenges, Advances and Platforms. Future Generation Computer Systems, 37. (2019), 105. 475-491. Online: https://doi.org/10.1016/j. future.2019.12.019

\section{Jogforrások}

Az Európai Parlament és a Tanács 2009/110/EK irányelv (2009. szeptember 16.) az elektronikuspénz-kibocsátó intézmények tevékenységének megkezdéséről, folytatásáról és prudenciális felügyeletéről, a 2005/60/EK és a 2006/48/EK irányelv módosításáról, valamint a 2000/46/EK irányelv hatályon kívül helyezéséről

Az Európai Parlament és a Tanács (EU) 2015/2366 irányelv (2015. november 25.) a belső piaci pénzforgalmi szolgáltatásokról és a 2002/65/EK, a 2009/110/EK és a 2013/36/EU irányelv és a 1093/2010/EU rendelet módosításáról, valamint a 2007/64/EK irányelv hatályon kívül helyezéséről

\section{ABSTRACT}

The Relationship between Cryptocurrencies and E-trust László DORNFELD

There is a heated discourse on cryptocurrencies in both public discourse and academia. Some see it as a pioneering technology of the future, while others are much more sceptical about its possibilities. In the investigation of cryptocurrencies, not only the need for anonymity and the exclusion of third parties should be emphasised, but also the role of trust, as it was invented due to the loss of trust in society, its inventors wanting to create a system that did not require trust to function.

The first paper in a multi-part study series summarising the results of one year of research presents conceptual issues and debates about cryptocurrencies, its theoretical foundations and operation and the key players of the market. The main purpose of this theoretical grounding is to provide a better picture on the basics of the topic, which will make the study on the relationship between cryptocurrencies and crime more comprehensible in later studies. At the same time, it allows for a complex approach, as it can provide insights into the interrelationships between e-trust and criminological aspects.

Keywords: cryptocurrency, blockchain, bitcoin, e-trust 